LUBLIN STUDIES IN MODERN LANGUAGES AND

LITERATURE 39 (2), 2015, HTTP://WWW.LSMLL.UMCS.LUBLIN.PL

\author{
Ebrahim Salimi-Kouchi \\ University of Isfahan, Isfahan, Iran \\ Mohsen Rezaeian \\ Shiraz University, Shiraz, Iran
}

\title{
"Dashed Hopes and Good Intentions": A Bourdieuian Reading of Edward Albee's Who's Afraid of Virginia Woolf?
}

\begin{abstract}
Pierre Bourdieu's investigation into the mechanism of power relations in any given society emphasizes that culture is firmly embedded in social lives of agents. An agent engages in some social competitions, struggling with others and his or her own limits. Applying the metaphor of "game" to social life, Bourdieu believes that people, in order to accumulate more capitals, participate in intense social competitions. Edward Albee's Who's Afraid of Virgina Woolf raises some questions about the nature of power, language, and their intersection. The lives of the characters are not far removed from how they experience power relations in a college campus, a microcosm of American society. Putting into practice Bourdieu's theory of practice, this article analyzes the influence of the accumulation of capitals in the lives of George and Martha, the role of the imaginary child as a part of American dream and its significance to the couple's lives, and ultimately the use and abuse of language in their ways of communication.
\end{abstract}

Keywords: Bourdieu, Albee, habitus, field, capital, imaginary son, American Dream, language 


\section{Introduction}

To attribute Pierre Bourdieu a single field of study proves impossible. Though he is mostly regarded as a sociologist of culture, he made substantial contributions to a broad range of fields including philosophy, sociology, anthropology, politics, culture and literary theory. Bourdieu's research into the mechanism of power relations in a given society emphasizes that culture is firmly embedded in social lives of agents. When situated in some seemingly disinterested realms (for instance, the school cafeteria), an agent engages in some social competitions, struggling with others as well as his or her own limits. Applying the metaphor of "game" to social life, Bourdieu believes that people participate in intense competitions:

constraints and demands of the game, although they are not restricted to a code of rules, impose themselves on those people - and those people alone-who, because they have a feel for the game, a feel, that is, for the immanent necessity of the game, are prepared to perceive them and carry them out. (Bourdieu 1990: 63).

$\mathrm{He}$ is interested in examining the various ways through which such struggles and competitions happen.

Edward Albee's Who's Afraid of Virgina Woolf raises questions about the nature of power, language, and their intersection. The lives of the characters are not removed from how they experience power relations, embedded in a milieu of a college as a microcosm of American society. The play's intricate interrelatedness of power and language can be analyzed through the lens of the theories whose core concept is power relations. Bourdieu's theory of practice sheds further light on the interconnected mechanism of power and language in a sociological context of Albee's play.

This article includes a brief introduction to the major concepts of Bourdieu's theory of practice such as habitus, field, cultural capital, bodily hexis and symbolic power. The first part of discussion shows how George's concern to accumulate more capitals affects his life and career and how Martha's loveless childhood influences her marital life. The second part pays attention to the significance of the imaginary son to the whole structure of the play. From this perspective, the play expresses the failure of the myth of American dream. Moreover, 
language as an integral element of the theatre of absurd draws special attention in the third part. The essay attempts to show that though language does not succeed in building verbal communication, the worlds of the characters are structurally verbalized.

\section{Bourdieu's theoretical concepts}

\subsection{Habitus}

Borrowing an Aristotelian concept, Bourdieu uses habitus in a specific way. In order to analyze the individual's practices, Bourdieu uses the term as opposed to structuralism's systematic predetermination of every action. To him, habitus is associated with "the dual need to conceptualize the subject's practice as such, and as having an origin that lay outside itself" (Dosse 1997: 304). In every social game the individual "need not adhere to the imposition of structural social codes to be able to work toward the end of his or her social advantage within a cultural dynamic" (Niro 2006: 295).

Habitus is comprised of a set of dispositions whereby every agent acts and reacts in certain ways in a specific social context. The practices, perceptions and attitudes of agents can be "objectively adapted to their outcomes without presupposing a conscious aiming at ends or an express mastery of the operations necessary in order to attain them" (Bourdieu and Wacquant 1992: 53). In other words, no conscious rules can govern these practices. Habitus is "the way society becomes deposited in persons in the form of lasting dispositions, or trained capacities and structured propensities to think, feel and act in determinant ways, which then guide them" (Wacquant 2006: 318). Therefore,

Habitus is neither a result of free will, nor determined by structures, but created by a kind of interplay between the two over time: dispositions that are both shaped by past events and structures, and that shape current practices and structures and also, importantly, that condition our very perceptions of these. (Bourdieu 1984: 170)

Habitus, in this sense, is created and reproduced unconsciously, "without any deliberate pursuit of coherence ... without any conscious concentration" (Bourdieu 1984: 170). "The dispositions learned both through bodily practice and through social categories allow agents to 
act without any strict conscious plan or calculation and to adjust, automatically, to the needs of the situation" (Chandler 2013: 471).

Habitus is constituted by the dispositions that are inculcated, structured, durable, generative and transposable (Thompson 1991: 12). Inculcation means that the memories of the past, childhood experiences, manners and the method of childhood training form human personalities. These dispositions are structured in a specific social milieu and individuals, according to their participations in social conditions, show some similarities and differences. Durability implies that dispositions, embedded in individual's life, endure as life experience and become parts of his or her history of life. Producing a diversity of practices and perceptions in a field, dispositions are also generative and transposable.

Not a fixed concept, habitus is an incessant process of change and construction "with individual's biography and stocks of capital in constant tension or alignment with the field" (Davey 2009: 278). Some factors such as knowledge, experience and entry to a new field determines the way habitus changes (ibid.).

\subsection{Field and symbolic power}

Habitus operates within a specific field. A field (game or market are interchangeably used) is a "structured system of social positionsoccupied either by individuals or institutions-the nature of which defines the situation for their occupants" (Jenkins 1992: 85). In other words, field is

$$
\begin{aligned}
& \text { a network, or configuration, of objective relations between positions. These } \\
& \text { positions are objectively defined in their existence and in the determinations they } \\
& \text { impose upon their occupants, agents or institutions, by their present and potential } \\
& \text { situation (situs) in the structure of the distribution of species of power (or capital) } \\
& \text { whose possession commands access to the specific profits that are at stake in the } \\
& \text { field, as well as by their objective relation to other positions (domination, } \\
& \text { subordination, homology, etc.). (Bourdieu and Wacquant 1992: 97) }
\end{aligned}
$$

Sometimes interconnected, various fields are not totally autonomous. Therefore, situated in different fields, a specific habitus may result in different practices. Such practices are 
the product of an encounter between a habitus and a field which are, to varying degrees, 'compatible' or 'congruent' with one another, in such a way that on occasions when there is a lack of congruence ..., an individual may not know how to act and may literary be lost for words. (Thompson 1991: 17)

The field of power is "the dominant or preeminent field of any society; it is the source of the hierarchical power relations which structure all other fields" (Jenkins 1992: 86). From Bourdieu's perspective, the mechanism of symbolic power is largely dependent on the dominant discourse or ideology (i.e. symbolic violence) of a given era. The dominant discourse establishes its favorite order as a natural order. Every agent feels it is natural to be congruent with the dominant discourse. The order itself is achieved through a process of misrecognition; the fact that individuals misrecognize an invisible power structure. Put it otherwise, misrecognition is "denial of the economic and political interests present in a set of practices" (Swartz 1997: 89). Bourdieu believes that the symbolic power is exercised "only through the complicity of those who do not want to know that they are subject to or even that they themselves exercise it" (qtd. in Swartz 1997: 89). Therefore, symbolic power is misleadingly proved to be legitimate. In other words, agents acknowledge the legitimacy of the symbolic power, hence the hierarchy of power relations. Symbolic power is "a legitimating power that elicits the consent of both the dominant and the dominated" (ibid.).

Every power to exert symbolic violence, i.e. every power which manages to impose meanings and to impose them as legitimate by concealing the power relations which are the basis of its force, adds its own specifically force to those power relations. (Bourdieu and Passeron 1977: 4)

The "active complicity" on the part of those who are subjected to symbolic power and hence the consequent legitimacy secure the endurance of the hierarchy (Thompson 1991: 23). The dominated do not perceive the arbitrary nature of this hierarchy which acts according to the benefits of some groups. The destruction of such symbolic hierarchy depends on agents' awareness of its arbitrary nature. 


\subsection{Capital}

Traditional Marxism places emphasis on the role of economic gain as a significant factor in social class structure and its consequent class conflict. Bourdieu also believes that society is a site of struggles. However, he holds that these struggles happen in a symbolic realm. Defining capital as "accumulated labor," he extends the concept of capital and speaks of its four generic types: economic (e.g., money and property), cultural (e.g., information, knowledge, and credentials), social (e.g., acquaintances and networks), and symbolic (e.g., legitimation, prestige, and authority) (Bourdieu 1986: 241).

Cultural capital, a source of power, is assumed to be a set of resources that puts an agent in higher position and status in a specific social context. "Symbolic capital is 'denied capital'; it disguises the underlying interested relations as disinterested pursuits"(Swartz 1997: 90). The significance of symbolic capital lies in its apparent negation of economic capital. "Symbolic capital is a form of power that is not perceived as power but as legitimate demands for recognition, deference, obedience, or the service of others" (ibid.). Not meaningful by themselves, such notions as prestige, authority and alike are considered expressive when the public take them as legitimate.

Bourdieu did not much discuss the notion of gender. In his view, women are not "capital-accumulating subject but they are capitalbearing object" (Lovell 2000: 20). By seeking the social construction of the bodily appearance, women create gendered forms of cultural capital and in effect redefine "the legitimate image of femininity" (Bourdieu 1984: 153). Women, through their charm and beauty, become an object through which men gather more capital. Introducing the notion of "feminine capital," Kate Huppatz holds that "the gender advantage derived from disposition or skill set learned via socialization or simply when members of a particular field recognize one's body as feminine" (qtd. in Thorpe 2009: 494).

\subsection{Bodily hexis}

The dispositions are deeply ingrained in body. "Bodily hexis," Bourdieu notes, "is political mythology realized, em-bodied, turned 
into a permanent disposition, a durable way of standing, speaking, walking, and thereby of feeling and thinking" (Bourdieu 1990: 69-70). The identities of men, women and different social groups are shaped and socially interpreted by the way they use the bodily dispositions and body language. Besides, when we use language, we do so as individuals with specific social and cultural histories.

\section{Discussion}

3.1. Accumulation of capital and bitterness of life

Bourdieu uses the language of economics to emphasize that the logic of economics operates within different fields. Individual's practices are directed to augment some kinds of capital, cultural or symbolic. Practice also intends to maximize profits such as prestige, honor and so forth. Put it otherwise, there is a link between "actions and interests, between practices of agents and interest they knowingly or unknowingly pursue" (Thompson 1991: 16). Power depends on two factors: person's position within the field and the amount of capital he or she possesses. Within a given field "People invest in historically and situationally defined cultural pursuit to improve their overall social position, with their activities rendering interest over time" (Orser 2004: 147).

The field of education or academia is the dominant field of Virginia Woolf. Within such a field professors and academicians show an interest in accumulating cultural and symbolic capital. George, as a participant of the field, is an associate professor of history. Because of his position, he is naturally endowed with some sorts of capital. He, both economically and symbolically, lives a life of welfare and prestige. Looking after the augmentation of his capital (symbolic capital) and maximizing the symbolic profit, he intends to promote at the New Carthage College. However, his promotion does not live up to his expectations. Unlike his fellow professors who reached the rank of full professorship, he is still an associate professor. Moreover, he became the department's head only during World War II, when most of the colleagues had served in the army. Therefore, instead of being "the History Department," he is only "in the History Department" 
(1.50). His failure to advance in the department leads to masochistic and cynic side of his personality.

Bitterness and cynicism become parts of thematic structure of the play. George's bitter view of life is evident, for instance, in his ridiculing Martha's father for his longevity (1.41). Furthermore, he talks about a disease, ABMAPHID. Creating from the initials of his academic degrees, he names it as "wonder drug" and a "disease of the frontal lobes" (1.37). He says to Nick: "Dashed hopes, and good intentions. Good, better, best, bested. How do you like that for a declension, young man? Eh?" (1.32). In other words, he emphatically implies a sense of decline in his college career.

In the field of academia the credentials and scholarly publications have a huge impact on the augmentation of the participants' symbolic capital. From Bourdieuian perspective, literary and artistic production, though appeared as disinterested, is not interest-free (Thompson 1991: 16). George makes a request for the publication of his book, "a book about a boy who murders his mother and kills his father" (2.137). However, the College president did not accept his bid for the publication. Within this academic situation in which the college president holds sway, George lays waste his powers (Falvey 2010: 246). He, "with his intellectual dexterity and sardonic wit, wastes his talent with pointless minutiae. His one attempt at creative mastery" is not accomplished successfully (Falvey 2010: 247). Once more George fails to promote academically and to increase his symbolic capital.

His cynicism, partially the result of his unfulfilled promises, becomes quite obvious when he severely attacks Nick's field of study, i.e. biology. As a professor of history, he believes that history is philosophically so different from biology that they are hard to be reconciled. He accuses biology of imposing homogeneity upon the individuality and believes that biologists are trying to make everybody alike at the price of sacrificing people's individuality whereas historians' major concern is the study of the variety of human experience. "Do you believe that," says George, "people learn nothing from history? Not that there is nothing to learn, mind you, but that people learn nothing?" (1.37). George, witnessing Nick's ambition and 
the successful progression of biology in the field of academia, is scared of losing the amount of symbolic capital he has accumulated so far. He accuses biologists of wiping out the diversity of civilization, putting value on history and the amount of symbolic capital he himself owns. History, says he,

will lose its glorious variety and unpredictability. I, and with me the ... surprise, the multiplexity, and sea-changing rhythm of ... history, will be eliminated. There will be order and constancy ... and I am unalterably opposed to it. (1.67)

To George, Nick's field of study is threatening the future of humanity, but it also puts George's symbolic capital on a lower position.

As the college president's son-in-law, George is privileged to take the first step firmly on the ladder of promotion in his college career and to augment his symbolic capital. However, his relationship with his wife is blatantly sordid and masochistic. Possessing both feminine capital (beauty and charm) and symbolic capital (the college president's daughter), Martha releases her talent and energy in two interconnected directions: her abusive behavior toward her husband and her sexually provoking conduct toward Nick. It seems that her flirtation with Nick is committed to abuse and insult George. She uses her feminine capital, her charm and beauty, to seduce Nick, though her overall attempt is not successful. Her futile attempt reverberates again the "theme of unfulfilled promise" (Konkle 2003: 52). It is also suggested by Martha in Act III: "Oh my, there is sometimes some very nice potential, but, oh, my! My, my, my. But that's how it is in civilized society" (3.189). Her feminine capital does not live up to her expectations. Though Martha considers herself as a great earth mother (both maternal and feminine), she leads a life of infertility and inadequacy. When George pretends to kill her with a shotgun, he, in fact, intends to destroy her role as a mother. Therefore, "Martha's illusions of power and fertility" is defeated (Clum 2005: 60). On a large scale, it implies that "civilized society has potential, but it does not perform up to that potential" (Konkle 2003: 52).

Men, in Albee's plays, do not "measure up ... neither George nor Nick can measure up to Daddy, Martha's ambitious, successful 
progenitor who is, for Martha, the measure of a man" (Clum 2005: 60). Martha's feelings toward George suffer from an inherent contradiction. On the one hand, she attempts to dominate her husband. For instance, she calls George "a blank, a cipher," (1.17) "a great ... big ... fat ... FLOP!" without "any ... personality," (1.84) "a man drowning"who lacks "the guts" to "rip me to pieces" $(2.135,158)$. She justifies her dominance because of "George's ... weakness and my ... necessary greater strength ... to protect himself ... and $u s "$ (3.222). On the other hand, despite her verbal attack against George, she still loves him. She falls for George, despite her plan to marry the heir-apparent (1.79), and she also insists that George's knockdown in the boxing match was accidental because he was "off balance" (1.56).

Dispositions which mold habitus endure throughout the life history of people. One must look at the childhood experiences to find out the ways people act in their adolescent life. As "a mobile, structured-yet structuring structure," habitus is "an account of how past moments of the shaping of the habitus are retained in the present" (Bennett 2007: 205). When Martha recounts her loveless childhood, a moment of self-doubt lurking beneath her pretended confidence is revealed:

Mommy died early, see, and I sort of grew up with Daddy. (Pause-thinks) ... I went away to school, and stuff, but I more or less grew up with him. Jesus, I admired that guy! I worshipped him ... I absolutely worshipped him. I still do. And he was pretty fond of me, too ... you know? We had a real ..., rapport going ... a real rapport. (1.77)

With this one-way relationship comes her loneliness. Her emotional abandonment becomes evident in her childish behavior in the Act III. She does not come to terms with the past because it is "the power of the past" that "constitutes the essential element of habitus" (Chandler 2013: 471). Put otherwise, it is the past that molds the egotistical nature of her character.

3.2. American Dream and the imaginary son

The creation of the imaginary son is the focal element of the play's structure. On the surface, George and Martha create the child to make their bond durable and to keep their frustrations at bay. From a wider 
perspective, adopting an imaginary child, linked with the myth of American dream, can be considered as an act of augmentation of symbolic capital. "The play," says Albee, "is an examination of whether or not we, as a society, have lived up to the principles of the American Revolution" (qtd. in Kolin 2005: 16-17). The ideological overtones of the American dream spread through the play. The naming of the characters is reminiscent of parts of America's history. George and Martha are named after George and Martha Washington, the First White House family, and Nick recalls Nikita Khrushchev, then the Soviet Union's leader. Added to these political implications is the ideal of having children as an integral part of American family. Having children is closely related to notion of the ideal family, consisting of parents and their children. This view of American family was dominant among American society during 1950s and 1960s. However, this notion, on a large scale, can be explained in terms of the mechanism of symbolic power. Misrecognition makes people accept the legitimacy of dominant ideology. George says that there are two options when you "can't abide the present": people can either "turn to a contemplation of the past ... or they can set about to... alter the future. And when you want to change something ... you BANG! BANG! BANG! BANG! (2.179-80). George himself prefers to alter the future. Despite Martha's heated anger, George exorcises the child because he has come to recognize the arbitrariness of the ideology. With the exorcism of the child, a symbol of their past, the couple face the future. As Matthew Roudané states, Albee recognizes "a moral decline fueled in part by the refusal of a large number of Americans to look beyond the surface platitudes of the day, and by the resulting banalization of national ideals and of Western civilization itself" (Roudané 2005: 43).

Furthermore, Nick, the imaginary son and the boy of George's story become various versions of American dream. It is not surprising that the appearance of imaginary child bears resemblance to both the boy of George's story and Nick. However, the story's boy and George himself live a life of cynicism, disappointment and bitterness. The imaginary child is exorcised and metaphorically loses his significance 
in George and Martha's renewed life. Nick is "physically beautiful, intelligent, ruthlessly ambitious, but missing some basic human qualities" and, at the play's end, his failure is regarded as the triumph of "George's intellect and sense of history ... over Nick's pragmatism" (Clum 2005: 60). This is consistent with Albee's analysis of American history not as progressive but as regressive one (Konkle 2003: 49).

\subsection{Language and violence}

Linguistic habitus, a sub-set of dispositions, is regarded as a specific way of learning how to speak or communicate in a given field such as family, school and so forth. Field of power is intricately related to the theme of language and symbolic power. Linguistic utterance as a form of practice is "the product of relation between a linguistic habitus and a linguistic market" (Thompson 1991: 17). Language is closely associated with the existence of institutions. From Bourdieu's perspective, institutions give the speaker the authority by means of which he or she is able to act or perform.

Instead of regarding language as a logical means of expression and communication, the theatre of absurd uses it as a tool for further confusion. Using jargon, clichés, and nonsense, the playwright of absurd drama indicates that language itself is intrinsically empty. When language fails to communicate, other communicating tools are inevitably searched. In Albee's dramatic world, violence is taken as an alternative to futility of communication through linguistic means.

In Virginia Woolf, language is assumed to be central to the existence of characters. The characters are college professors and their wives. Based on their level of education, the professors use fluent and precise language. Endowed with a more precise and superior use of language, George is linguistically superior to Martha. Confronting the verbal attack and adolescent vocabulary of his wife, George is indirect, ironical and restraint. However, he fails to communicate with his wife and others. As a result, verbal and physical violence pervades. In an attempt to make communication with Nick, George says: "you disgust me on principle, and you're a smug son of a bitch personally, but I'm trying to give you a survival kit," (2.134). George's acts of 
shooting Martha and grabbing her by throat are quite obvious acts of violence. George seriously warns Martha not to reveal the existence of the phantom child. In this drama of marital feud, when the secret is divulged, violence rules their relationship. They are unable to communicate except through violence and aggressiveness.

However, though verbal communication fails, language itself, as Jeanette Malkin points out, becomes "a relational gauge through which the definition of their reality is constantly, and violently, negotiated" (Malkin 1992: 167). Their existence is "constantly verbalized" and "even the central event of their lives-their joint son-is no more than a verbal elaboration, a fiction" (ibid., 173). George and Martha feel "the constant need to compete and outdo each other" (ibid., 171) and, therefore, for them, "to misuse language is ... a sign of weakness, and carries an immediate loss of power" (ibid., 168). In sum, though the language is not an appropriate tool of communication, the characters' existence and actions depend on the use or abuse of language. That is why Martha, at the play's end, comes to face the naked reality lurking beneath the self-consciously constructed illusion of the imaginary son.

\section{Conclusion}

Edward Albee's Who's Afraid of Virginia Woolf? focuses on the situation of individuals within the field of academia and, on a broad scale, American society. Within such a field, agents strive to accumulate more capitals, both cultural and symbolic. The amount of such capitals as academic degrees, credentials and publications determine the academic status of professors. In addition, the field of power utilizes some sorts of mechanisms to legitimize the ideological hierarchy. Misrecognizing the established hierarchy, agents are oblivious of the arbitrary nature of dominant ideology. Accordingly, the notion of the ideal family as a part of American dream is compatible with dominant power discourse. George, a participant in the field of academia, becomes aware of the arbitrariness of the mechanism of power and, consequently, the imperativeness of the exorcism of the child. 
Habitus, a set of dispositions, plays a significant role in the lives of people. To a large extent, an agent's future life reflects the embedded dispositions he or she has experienced. George and Martha's adulthood contains echoes of their childhood experiences and memories. However, habitus resists stability and undergoes some changes. George's decision to get rid of the illusion and to encounter the reality rescues their marital life. At sunrise, a ray of hope is felt.

As a university professor, George uses some linguistic forms which are more deliberate than Martha's use of language. In absurd drama, language loses its communicating capacity and violence becomes a major tool of communication. Throughout the play either verbal or physical violence is pervasive. However, the existence of George and Martha and especially their imaginary son are verbalized. In other words, language speaks them; it brings the couple and their world into conscious existence. Though they live in a world of illusion, their consciousness and perceptions are shaped by language.

\section{References}

Albee, E. (1962): Who's Afraid of Virginia Woolf: A Play. New York: Scribner.

Bennett, T. (2007): Habitus Clivé: Aesthetics and Politics in the Work of Pierre Bourdieu. New Literary History. 38.1: 201-228.

Bourdieu, P. (1984): Distinction: A Social Critique of the Judgment of Taste. London: Routledge.

Bourdieu, P. (1990): In Other Words. Stanford: Stanford University Press.

Bourdieu, P. (1986): The Forms of Capital. Trans. Richard Nice. The Handbook of Theory and Research for the Sociology of Education. Ed. John G. Richardson. New York: Greenwood. 243-48.

Bourdieu, P. (1990): The Logic of Practice. Trans. Richard Nice. Stanford: Stanford University Press.

Bourdieu, P., Passeron, J. C. (1977): Reproduction in Education, Society and Culture. London: Sage.

Bourdieu, P., Wacquant, L. J. D. (1992): An Invitation to Reflexive Sociology. Chicago: The University of Chicago Press.

Chandler, B. (2013): The Subjectivity of Habitus. Journal for the Theory of Social Behaviour. 43.4 : 469-91.

Clum, J. M. (2005): Withered Age and Stale Custom: Marriage, Diminution, and Sex in Tiny Alice, A Delicate Balance, and Finding the Sun. The Cambridge 
Companion to Edward Albee. Ed. Stephen Bottoms. Cambridge: Cambridge University Press. 59-74.

Davey, G. (2009): Using Bourdieu's Concept of Habitus to Explore Narratives of Transition. European Educational Research Journal. 8.2: 276-84.

Dosse, F. (1997): History of Structuralism: the Sign Sets, 1967-present. Vol. 2. Trans. Deborah Glassman. Minneapolis: University of Minnesota Press.

Falvey, K. (2010): Dark Humor in Edward Albee's Who's Afraid of Virginia Woolf? Bloom's Literary Themes: Dark Humor. Ed. Blake Hobby. New York: Infobase Publishing. 241-49.

Jenkins, R. (1992): Pierre Bourdieu. New York: Routledge.

Kolin, P. C. (2005): Albee's Early One-Act Plays: A New American Playwright from Whom Much Is to Be Expected. The Cambridge Companion to Edward Albee. Ed. Stephen Bottoms. Cambridge: Cambridge University Press. 16-38.

Konkle, L. (2003): Good, Better, Best, Bested: The Failure of American Typology in Who's Afraid of Virginia Woolf. Edward Albee: A Casebook. Ed. Bruce J. Mann. New York: Routledge. 47-63.

Lovell, T. (2000): Thinking Feminism with and against Bourdieu. Feminist Theory. 1.1: $11-32$.

Malkin, J. R. (1992): Verbal Violence in Contemporary Drama: From Handke to Shepard. Cambridge: Cambridge University Press.

Niro, B. (2006): The Social and the Cultural: Michel de Certeau, Pierre Bourdieu and Louis Marin. Modern European Criticism and Theory: A Critical Guide. Ed. Julian Wolfreys. Edinburgh: Edinburgh University Press. 292-301.

Orser, C. E. (2004): Race and Practice in Archaeological Interpretation. Pennsylvania: University of Pennsylvania Press.

Roudané, M. (2005): Who's Afraid of Virginia Woolf?: Toward the Marrow. The Cambridge Companion to Edward Albee. Ed. Stephen Bottoms. Cambridge: Cambridge University Press. 39-58.

Swartz, D. (1997): Culture and Power: the Sociology of Pierre Bourdieu. Chicago: University of Chicago Press.

Thompson, J. B. (1991): Editor's Introduction. Language and Symbolic Power. By Pierre Bourdieu. Cambridge: Polity Press. 1-31.

Thorpe, H. (2009). Bourdieu, Feminism and Female Physical Culture: Gender Reflexivity and the Habitus-Field Complex. Sociology of Sport Journal. 26: 491516.

Wacquant, L. J. D. (2006): Habitus. International Encyclopedia of Economic Sociology. Eds. Jens Beckert and Milan Zafirofski. London: Routledge. 317-21. 